\title{
AWARD FOR THE BEST PROPOSAL OUTLINING A PROGRAM OF RESEARCH IN JURIMETRICS- THE SCIENTIFIC STUDY OF LAW
}

The Center for the Study of Law, Science, and Technology of the Arizona State University, College of Law announces an award of ten thousand dollars for the best proposal outlining a program of research in jurimetrics-the scientific study of law. This research encompasses quantitative investigation or experimentation concerning law and the legal system.

Submissions should reflect vision, imagination, and insight that will provide intellectual stimulus in discerning a range of problems and suggesting a variety of empirical approaches to improvement of law, legal process, and legal institutions in the 21st century. Further information on the type of proposal being sought and the process for applying is available in recent issues of Jurimetrics: The Journal of Law, Science, and Technology or at: www.law.asu.edu/programs/sci-tech/jur-resaward.htm 